\title{
The Role of the Librarian in Faculty Research
}

\section{Robert Grover and Martha L. Hale}

Librarians traditionally have provided passive or reactive levels of service in academic libraries. This paper proposes that librarians assume a proactive role in the research process and that this can be accomplished through understanding research in the information transfer process and the role of the researcher. The librarian can and should be a key player in the research process. The role of the researcher and a proposed role for the academic librarian are outlined.

he issue addressed by this paper is the role of the librarian in faculty research at a college or university. First, this paper will review common library services. In order to examine the nature of research, two models will be presented: the first describes the academic researcher's patterns of research, while the second suggests the librarian's role in the research process. The final section of this paper will draw implications from the models for the researcher, the librarian, and library service.

\section{THE ISSUE}

Traditionally, the role of the librarian in a college or university has been supportive of the teaching and research roles of faculty and students. The level of service can be categorized as either passive or reactive. Librarians oversee the purchase of library materials, often in consultation with the faculty, and the availability of these materials for use may be considered a passive level of service. Other services are made available upon request; an example is the reserve book service or the production of bibliographies to support the teaching role of faculty. Such services are examples of the reactive level of service.

While the level of educational services has been criticized and a more assertive level proposed, little attention has been paid to the research role of the faculty member or to the potential assertive level of library service that might be rendered. ${ }^{1}$ Presently, most librarians offer reactive research services such as database searching which results in the production of a bibliography that may or may not include abstracts. The database search often results in overkill: too many citations, most having little or no relevance to the problem under study by the researcher. Don Swanson has suggested that it is the librarian's role to understand the research process and to create suitable aids for organizing and facilitating it. ${ }^{2}$ However, that role has neither been explored nor articulated in professional literature.

Until now, faculty researchers have been satisfied with the passive and reactive level of service offered in most academic libraries; however, the proliferation of information associated with the infor-

Robert Grover is Director and Professor at the School of Library and Information Science, University of South Florida, Tampa, Florida 33620; and Martha L. Hale is Dean and Associate Professor at the School of Library and Information Management, Emporia State University, Emporia, Kansas 66801. An earlier version of this paper was presented at the annual conference of the College and University Libraries Section, Kansas Library Association, October 9, 1986. 
mation age may require a more assertive level of service. If, as John Naisbitt has asserted, scientific and technical knowledge doubles every 5.5 years, the efforts of faculty to remain current in their narrow fields of research-at the "frontier" of knowledge-will become increasingly difficult. ${ }^{3}$ It will be even more difficult for the faculty member to stay current with his/ her broader discipline, especially in those areas within the discipline that are not directly related to the faculty member's research.

An additional problem for the researcher is the interdisciplinary nature of much research today. Increasingly, researchers are striving to integrate related areas within their disciplines to new knowledge they are creating, or they are trying to relate allied disciplines by stating theories from other disciplines and testing these theories in their own area of inquiry. A shift has occurred, at least in social science research, from the Cartesian mode of dualistic thought to a more holistic and relativistic point of view. ${ }^{4}$

What is the reason that library service has been unable to progress beyond the passive or reactive level of service to a more proactive or assertive level which will support and augment the work of the researcher? We submit that the reason lies in librarians' lack of understanding of the research process. Librarians are not educated as researchers; those who have doctorates usually are the directors of libraries and too busy with their administrative chores to work with faculty researchers. While library schools often require one research course, that course can be considered little more than an introduction to research methods so that students will be more discriminating readers of research; or it will enable them to design and conduct simple research projects for the purpose of making management decisions or for evaluating services or systems. At best, most library school graduates may be enlightened consumers of research. Certainly, librarians are not (and are not expected to be) as proficient at research as are the faculty with whom they work. However, librarians can play a crucial role in the research process; that role is delineated below.

\section{ACADEMIC RESEARCH}

In order to further an understanding of faculty research it is helpful to examine the framework in which new knowledge is created. For this we turn first to the sociology of information, then to an explanation of the research role.

\section{Sociology of Information}

The sociology of information has been described by Roger Greer and by Robert Grover and Jack Glazier. ${ }^{5}$ Briefly stated, each social group has its own culture, including a value system, which affects the patterns for creating, recording, producing, disseminating, organizing, diffusing, and preserving information and knowledge. A group of people shares a view of the world which enables them to filter or select the information they believe is acceptable. Kenneth Boulding has asserted that every individual filters information as a result of the various values provided by group memberships and personal experiences; indeed, he contends that there are no facts, only perceptions of stimuli that may be shared because of the shared knowledge provided by membership in groups. ${ }^{6}$

\section{"Fundamental to an understanding of the research process-the creation of new knowledge-is the paradig- matic structure of a discipline or pro- fession."}

Fundamental to an understanding of the research process - the creation of new knowledge-is the paradigmatic structure of a discipline or profession. ${ }^{7}$ A discipline is a social group with a shared body of knowledge. Within a discipline are several schools of thought, or paradigms, which include favored theories, research methods, leading thinkers, and even graduate schools for doctoral students who will conduct the paradigm's research. A paradigm as described by Nicholas Mullins may be thought of as a "cluster": a group of researchers and their students who share the same theoretical framework and 
value system, conduct and publish research, and teach their paradigm. ${ }^{8}$ The librarian must identify the leading paradigms in a discipline and relate them to the campus researchers and their work. The paradigmatic perspective of the faculty researcher will serve as a major filter of information the faculty member will choose to use in conducting a literature review, selecting research methodologies, analyzing data collected, interpreting results, and writing the research report.

Psychology provides an example of a discipline with multiple paradigms.' One of psychology's paradigms is behaviorism. Behaviorists embrace a value system constructed around behavioral science, a theory of human behavior as a response to stimuli. The behaviorists favor experimental research methods. Another paradigm in psychology is instinctivism, whose adherents view human behavior as a manifestation of internal inheritance tendencies; their primary research methods is factor analysis. The developmental theorists, those who adhere to the paradigm of developmental psychology, prefer longitudinal studies, which can measure change over a period of time. A final example is the psychoanalytic paradigm, where the primary research method is the intensive, open-ended interview.

The process of tuning in to faculty research should begin by identifying the paradigms taught and used to guide research in the various disciplines on campus. For example, a campus may house a group of psychologists that adheres to the behavioral paradigm, but there may not be one that adheres to the psychoanalytic paradigm.

\section{Research Role}

In addition to understanding the focus of the faculty members' discipline and paradigm, it is necessary to explore the research role. The faculty researcher spends her time reading, talking with colleagues and students, reviewing for class, and trying to set aside one day a week for research. The popularly accepted view of research is very heavily influenced by the scientific method learned in elementary school. The image is of the researcher methodically choosing a topic, conducting a literature review, designing a data collection process, gathering the data, analyzing the data, and reporting the results. ${ }^{10}$

This prevailing view assumes that research is a systematic process which builds upon previously accepted knowledge. While such an ideal is an easy process to teach and fits a sense of logic and order, it may not describe reality because research is a creative activity. ${ }^{11}$ As suggested by $C$. Wright Mills, research involves a "serendipity factor," i.e., an element of chance discovery. ${ }^{12}$ When solving problems and building theories, researchers seldom operate in a carefully calculated, linear, sequential pattern. Researchers are thinking about their research and problems they are attempting to solve at random moments-driving to work, watching the evening news, talking with a friend, taking a shower. Since theories are generalized statements about relationships, new relationships may be identified after observing another related event, and the researcher suddenly gets a new idea, perhaps an entirely new perspective or "breakthrough." The randomness of the research process has been documented in such books as Sociologists at Work and The Double Helix. ${ }^{13}$

The researcher's use of the library also is random. The notion that a researcher identifies a problem and conducts a literature search before extrapolating hypotheses is usually not the way social science researchers work. Most researchers seek to add new knowledge to an area in which they are already knowledgeable and in which they have already completed some research. The invisible college-networks of colleagues who share research interests-and the refereeing processes often keep them informed of newly created literature in draft or prepublication form. Telephone calls or conversations at conferences often provide stimulus for their next work. The paradigm in which they work strongly influences what researchers are willing to perceive as a researchable problem and the appropriate research methods to address the problem. The site, client population, and depth of the study are often influenced by such practical realities as opportunity, friends, and money. ${ }^{14}$ The first material searched is probably that 
which the researcher already knows and can mentally review. If the documents themselves need to be reexamined they are often retrieved from office shelves or files, or by graduate assistants. Copies may be borrowed from colleagues down the hall. Often a phone call to a friend or another author may be perceived as the quickest access to the idea. In reality, the researcher wants the answer to a question, not the literature. For example, a researcher who has been studying subject retrieval and has recently discovered the Dreyfus model may wonder if researchers in the field of artificial intelligence have used this model.

When a researcher is beginning to explore a new area of investigation, i.e., when she is not yet an expert, she may be more dependent on such formal sources of information as the library. Even then, the search for the literature may center on a review of citations used in related articles she already owns. ${ }^{15}$ It is still unknown how subject searches are used as a part of the research process. It is most likely that they are used to fill in the gaps or to bolster a point the author wishes to make rather than as the entry into an area.

In short, literature may actually be as much a part of the writing or reporting process as the research process. This does not suggest that the library is useless to the researcher, but it does suggest that the librarian's approach might be more effectively shifted.

\section{Librarian's Role}

Role theory suggests that in order to assume a proactive supporting role, the librarian must understand the primary player's role. It is possible that the primary player has altered her role and an updated understanding of the new approach may be necessary before the librarian can narrow his or her distance from this researcher.

In other words, the role of the librarian in the research process is to anticipate the researcher's patterns. Throughout the research process, faculty members rely on people whom they perceive to have needed knowledge. The assertive librarian should be a person the researcher knows and respects as an information resource whether the question is, Has Weick changed his opinion on planning since his 1969 book? or Who else supports my ideas but uses different terms? The librarian who does not have to ask, "Who's Weick?" or "What are your ideas?" is sufficiently tuned in to the faculty member's research to be of use to the researcher. In short, the assertive librarian is a member of the researcher's "visible" college.

Such a role is strengthened if the librarian anticipates the interests of the researcher. An increasing amount of contemporary research is interdisciplinary, as noted above. For example, sociological or psychological theory may be applied to analysis of literature. Another example would be the application of psychology, sociology, or management theory to librarianship or to other professional fields. Librarians, who tend to be generalists, can serve as the bridge or focal point for building literature linkages if librarians are familiar with the leading paradigms in the faculty member's discipline. By understanding the research questions that are examined by the researcher as well as knowing the literature that is appearing in journals and on the library shelves, the librarian can introduce the researcher to people and ideas from multiple disciplines, fostering a network.

The networking concept can extend beyond the literature and a researcher. Networking can be done through the consultation process or through research forums sponsored by the library. These forums might bring together researchers from the humanities, social sciences, and sciences who would discuss research methods, paradigms, issues, and implications for interdisciplinary work. Research is a creative process which relies heavily upon invisible colleges. The librarian, who usually works with faculty from several academic units, may be able to assist network building by referring one researcher to another.

Another stage in the research process where the librarian can facilitate the production of new knowledge is in the analysis of data and interpretation of results. Here, too, the librarian can facilitate net- 
working so that the researcher may solicit ideas, statistical expertise to assist in analysis, or an expert in another discipline to assist in relating findings to work in an allied area of inquiry. Faculty are experts in their field, and librarians usually do not believe that faculty need the bibliographic counseling of librarians; however, the access points to a discipline are ever changing; new databases are being developed, and new bibliographic sources are published. Librarians can be benefactors to researchers by informing them of pertinent access points. Likewise, the researcher can serve as a resource to the librarian who is constructing a database for researchers, providing guidance in the use of retrieval terms, and identifying pertinent information sources. Librarians and researchers must form partnerships in order to facilitate the research process.

\section{IMPLICATIONS}

Our concern, expressed in the introduction to this article, is that academic librarians must become more intimately involved in the research process; they must become more proactive. We have proposed a model which will enable librarians to assume that assertive role through a greater understanding of the faculty research process.

\section{"Librarians who are familiar with leading paradigms within disci- plines can work more effectively with faculty researchers."}

Librarians who are familiar with leading paradigms within disciplines can work more effectively with faculty researchers. This help can occur at one of several stages in the research process. First, the librarian can be of assistance in the process if the researcher enters new literature in order to identify published research related to the problem the researcher is addressing. The librarian must be aware of the paradigm to which the researcher subscribes in order to ask probing questions during the ques- tion negotiation process as the information needs are diagnosed. The librarian can determine the paradigmatic perspective of the researcher through a carefully considered interview with questions pertaining to key terms utilized by researchers in the field, research methods used, what the researcher knows about previous findings on the problem, and names of leading scholars working on related problem areas. An expanded version of the faculty client file suggested by Calvin Boyer can systematically record such findings. ${ }^{16}$ The proactive librarian can use this knowledge to conduct a search (manual and/or database) to update the researcher so that the researcher is well informed of contemporary thinking and efforts toward problem solving in the area of inquiry.

Knowledge of faculty researchers' work can also provide guidelines for librarians who are engaged in collection building. Selection of monographs and serials could be guided by knowledge of the paradigms to which researchers subscribe. Communication with researchers will assist in the selection of pertinent resources to support research in the discipline and in allied disciplines.

As noted earlier, librarians can facilitate networking among researchers on other campuses and among disparate paradigms, disciplines, or professions. The librarian can use this knowledge of the research process, the paradigms, and membership in those paradigms, together with his own network of librarians and scholars, to link scholars and their ideas. Of course, the librarian has available the directories and databases that can be key factors in networking, but the librarian's awareness of the research process and knowledge of research on his campus are of paramount importance in networking.

Another implication for tuning in to faculty research is that it gives the librarian his or her own area of research. The librarian who understands the research process by doctoral students or faculty members in a particular discipline then has something of importance to report to the library profession about knowledge creation. Research on knowledge creation has implications for the research librarians who work 
with researchers and can help them work together more effectively. In other words, the study of the paradigms and creative process of research can benefit the work of librarians and contribute to scholarly productivity at universities.

In order to provide these services to researchers, librarians must have the intellectual background acquired through formal education and reading. In addition, a librarian must know how to be a quick study-how to consult specialized encyclopedias, handbooks, bibliographies, and other standard information sources in order to understand the paradigmatic structure and issues in an area of inquiry. The librarian must understand the information transfer patterns in a discipline and be able to discern those patterns through a perusal of that discipline's literature and through interviews with scholars. We believe that this type of scholarship is both possible and desirable; in fact, the study of information transfer should be a fundamental part of education for the library profession. ${ }^{17}$

A final implication is the cost of this more proactive role for librarians. While it is not possible for a librarian to participate in the invisible college of the scores of researchers with whom the academic librarian works, neither is it likely that all of those faculty will respond to the proactive research services we propose. We suggest that librarians implement and promote their new research services with those faculty who perceive them as important. Success with the faculty members who adopt the new services early will help promote research services as word spreads through the faculty network. As the research services are used more extensively, it may be necessary for the library staff to assess all services offered, and reallocation of staff time and resources may be required to meet research needs.

\section{CONCLUSION}

We have asserted that college and university librarians typically provide educational and research services at the passive or reactive level. We speculate that librarians have not been more proactive with research services because their education has not provided them enough expertise and they do not understand the research process; however, professional education should include the study of information transfer and the sociology of information.

Because research is a critical component of our information age, we have proposed a model for library service which interjects the librarian directly into the research process. By understanding the role of the researcher, the sociology of information, and the creative research process, librarians can facilitate research by acting as networkers-persons who link one researcher to others. Also, as information specialists, librarians can introduce researchers to related literature and researchers in allied disciplines.

In order to serve as a broker, the librarian must be a scholar willing to make judgments so that recommendations can be made. This scholarship must include knowledge in a discipline as well as knowledge of the sociology of information, particularly the creation of new knowledge. To be effective, librarians must realize that the research process is creative, serendipitous, and enhanced through invisible colleges-networks of scholars. The challenge of academic librarians today is to become key members of these research networks and fully recognized faculty members of the invisible colleges.

\section{REFERENCES}

1. Pauline Wilson, "Librarians as Teachers: The Study of an Organization Fiction," Library Quarterly 49:146-62 (Apr. 1979); Orvin Lee Shiflett, Origins of American Academic Librarianship (Norwood, N.J.: Ablex, 1981), p. 227-37; Lynn E. Birge, Serving Adult Learners: A Public Library Tradition (Chicago: American Library Assn., 1981); Nigel Ford, 'Towards a Model of 'Library Learning' in Educational Systems," Journal of Librarianship 11:247-60 (Oct. 1979); Robert Jordan, "The 
'Library-College'-A Proposal," in The Library College, ed. Louis Shores, Robert Jordan, and John Harvey (Philadelphia: Drexel Pr., 1966); Willie L. Parson, "User Perspective on a New Paradigm for Librarianship," College \& Research Libraries 45:370-73 (Sept. 1984).

2. Don R. Swanson, "Libraries and the Growth of Knowledge," Library Quarterly 49:3-25 (Jan. 1979).

3. John Naisbitt, Megatrends: Ten New Directions Transforming Our Lives (New York: Warner, 1982).

4. Fritjof Capra, "The Turning Point: A New Vision of Reality," The Futurist 16:19-24 (Dec. 1982); Peter Schwartz and James Ogilvy, The Emergent Paradigm: Changing Patterns of Thought and Belief, Analytic Report 7, Values and Lifestyle Program (Menlo Park, Calif.: SRI International, 1979).

5. Roger C. Greer, "A Model for the Discipline of Information Science" in Intellectual Foundations for Information Professionals, ed. Herbert K. Achleitner (New York: Social Science Monographs, 1987: dist. by Columbia Univ. Pr.), p. 3-20; Robert Grover and Jack Glazier, "Information Transfer in City Government," 'Public Library Quarterly 5:9-27 (Winter 1984); Robert Grover and Jack Glazier, "Implications for Application of Qualitative Methods to Library and Information Science Research," Library and Information Science Research 7:247-60 (July-Sept. 1985).

6. Kenneth E. Boulding, The Image: Knowledge in Life and Society (Ann Arbor, Mich.: Univ. of Michigan Pr., 1956).

7. Robert Grover and Jack Glazier, "A Proposed Taxonomy of Theory: A Conceptual Framework for Theory Building in Library and Information Science," Library and Information Science Research 8:227-42 (July-Sept. 1986).

8. Nicholas Mullins, Theories and Theory Groups in Contemporary Sociology (New York: Harper, 1973).

9. Arnold M. Rose, "The Relation of Theory and Methods," in Sociological Theory: Inquiries and Paradigms, ed. Llewellyn Gross (New York: Harper, 1967), p. 209-10.

10. Paul D. Leedy, Practical Research: Planning and Design, 2d ed. (New York: Macmillan, 1980).

11. Rebecca Kellogg, "Beliefs and Realities," College \& Research Libraries News 47:492-96 (Sept. 1986); Don R. Swanson, "Undiscovered Public Knowledge," Library Quarterly 56, no.2:103-18 (Apr. 1986); Richard L. Daft, "Learning the Craft of Organizational Research," Academy of Management Review 8:539-46 (Oct. 1983).

12. C. Wright Mills, The Sociological Imagination (New York: Oxford Univ. Pr., 1959).

13. Phillip E. Hammond, ed., Sociologists at Work: Essays on the Craft of Social Research (New York: Basic Books, 1964); James D. Watson, The Double Helix (New York: New Amer. Lib., 1968).

14. Hammond, Sociologists at Work.

15. B. J. H. Van Styvendaele, "University Scientists as Seekers of Information: Sources of References to Periodical Literature," Journal of Librarianship 9:271-77 (Oct. 1977).

16. Calvin Boyer, "Faculty Client Files," Guest Editorial, College \& Research Libraries 47:533-34 (Nov. 1986).

17. Robert Grover, "Library and Information Science Education for the Learning Society: A Model Curriculum," Journal of Education for Library and Information Science 26:33-45 (Summer 1985). 